\title{
Microcystin Incidence in the Drinking Water of Mozambique: Challenges for Public Health Protection
}

\author{
Isidro José Tamele ${ }^{1,2,3}$ (D) and Vitor Vasconcelos $1,4, *$ (D) \\ 1 CIIMAR/CIMAR - Interdisciplinary Center of Marine and Environmental Research, University of Porto, \\ Terminal de Cruzeiros do Porto, Avenida General Norton de Matos, 4450-238 Matosinhos, Portugal; \\ isitamele@gmail.com \\ 2 Institute of Biomedical Science Abel Salazar, University of Porto, R. Jorge de Viterbo Ferreira 228, \\ 4050-313 Porto, Portugal \\ 3 Department of Chemistry, Faculty of Sciences, Eduardo Mondlane University, Av. Julius Nyerere, n 3453, \\ Campus Principal, Maputo 257, Mozambique \\ 4 Faculty of Science, University of Porto, Rua do Campo Alegre, 4069-007 Porto, Portugal \\ * Correspondence: vmvascon@fc.up.pt; Tel.: +351-223-401-817; Fax: +351-223-390-608
}

Received: 6 May 2020; Accepted: 31 May 2020; Published: 2 June 2020

check for updates

\begin{abstract}
Microcystins (MCs) are cyanotoxins produced mainly by freshwater cyanobacteria, which constitute a threat to public health due to their negative effects on humans, such as gastroenteritis and related diseases, including death. In Mozambique, where only $50 \%$ of the people have access to safe drinking water, this hepatotoxin is not monitored, and consequently, the population may be exposed to MCs. The few studies done in Maputo and Gaza provinces indicated the occurrence of MC-LR, $-\mathrm{YR}$, and $-\mathrm{RR}$ at a concentration ranging from 6.83 to $7.78 \mu \mathrm{g} \cdot \mathrm{L}^{-1}$, which are very high, around 7 times above than the maximum limit $\left(1 \mu \mathrm{g} \cdot \mathrm{L}^{-1}\right)$ recommended by WHO. The potential MCs-producing in the studied sites are mainly Microcystis species. These data from Mozambique and from surrounding countries (South Africa, Lesotho, Botswana, Malawi, Zambia, and Tanzania) evidence the need to implement an operational monitoring program of MCs in order to reduce or avoid the possible cases of intoxications since the drinking water quality control tests recommended by the Ministry of Health do not include an MC test. To date, no data of water poisoning episodes recorded were associated with MCs presence in the water. However, this might be underestimated due to a lack of monitoring facilities and/or a lack of public health staff trained for recognizing symptoms of MCs intoxication since the presence of high MCs concentration was reported in Maputo and Gaza provinces.
\end{abstract}

Keywords: drinking water quality; microcystin; Mozambique; public health

Key Contribution: This review will contribute to the implementation of an operational monitoring program of MCs in order to reduce or avoid the possible cases of intoxications since the drinking water quality monitoring protocol recommended by the Ministry of Health does not include MC tests.

\section{Introduction}

Mozambique (Figure 1) is a country located in southeastern Africa $\left(10^{\circ} 30^{\prime}-26^{\circ} 52^{\prime} \mathrm{S}\right.$ and $40^{\circ} 50^{\prime}-30^{\circ} 31^{\prime}$ E) covering a total land area of $800,000 \mathrm{~km}^{2}$. It is bathed by the Indian Ocean in the east and makes borders with Tanzania in the north; Malawi and Zambia in the northwest; Zimbabwe in the west and Swaziland and South Africa in the southwest. 


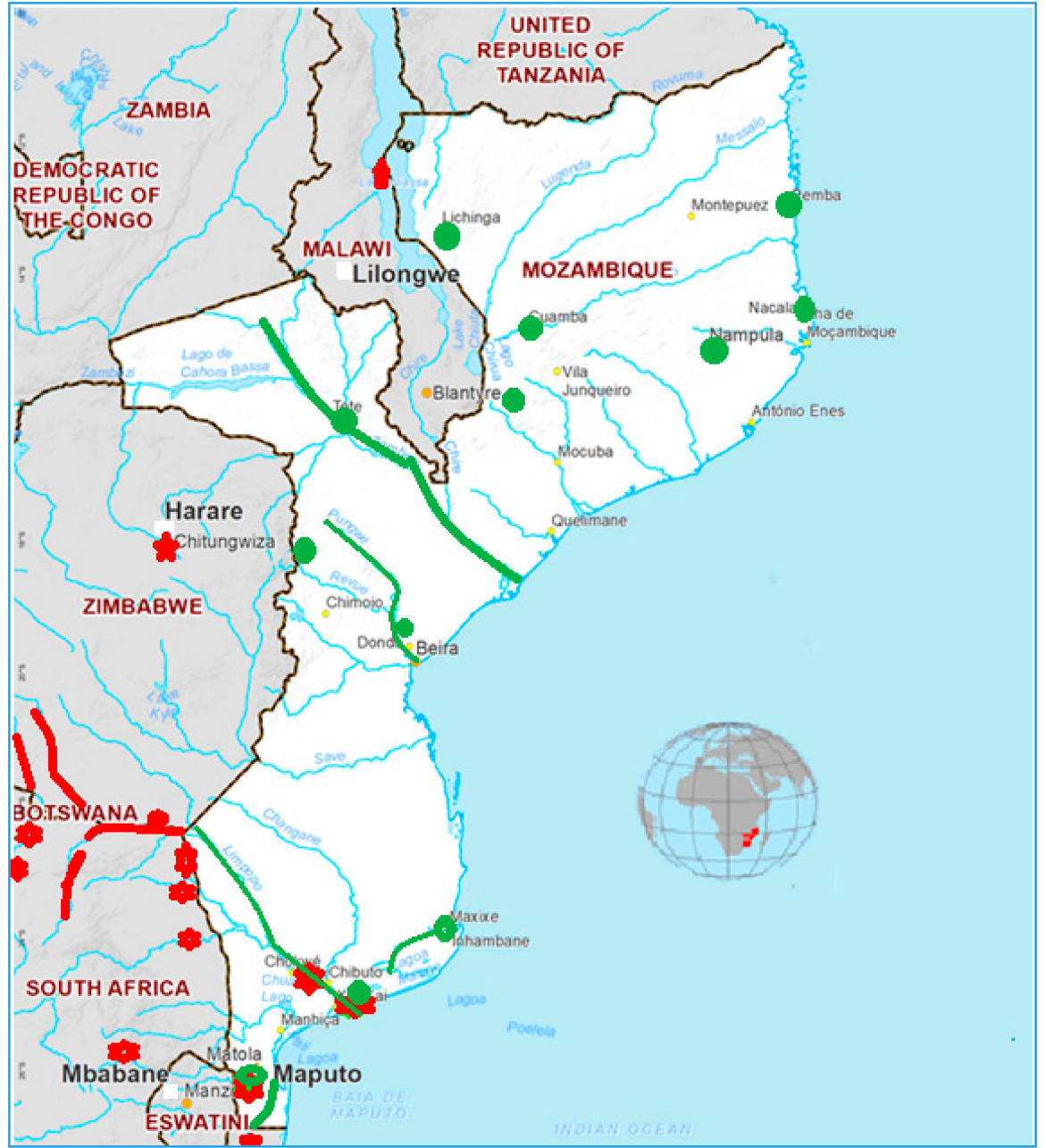

Figure 1. Map of Mozambique. Red points or lines indicate the sites where Microcystin (MC) or MC producers were detected in Mozambique, and in near sites or in the shared rivers with Mozambique, Green points indicate the water sources or water treatment centers.

According to IV populational census carried out in 2017, this country has 29.67 million habitants distributed in 11 provinces [1]. The climate of Mozambique varies from subtropical climates (north and center) to dry arid (south) [2]. Like many African countries, Mozambique is highly vulnerable to climate variability and extreme weather events (droughts, floods, and tropical cyclones) [3]. Droughts are the most frequent natural disaster that have a negative impact on the population that reside in these rural areas [4]. The location of Mozambique in the coastal area makes it vulnerable to floods since many transnational river basins end [2]. Unfortunately, only $50 \%$ of the population has access to "safe drinking water". Urban areas are the most favored, with $80 \%$, while rural and most of the population have only $35 \%$ coverage and consume untreated water daily from rivers, lakes, and small puddles that form after or during the rain [5-7], putting at risk public health.

Eutrophication of freshwater resources may lead to the occurrence of cyanobacterial blooms and the presence of cyanotoxins, being microcystins (MC), the most common toxins worldwide [8]. The presence of MC in untreated drinking water is a major threat to public health because this potent cyanotoxin causes hepatotoxicity in humans. Thus, this review evaluates the incidence of MC and its producers in drinking water bodies of Mozambique, based on reported and available data and the estimated human illness case numbers and associated economic damage caused by Microcystin both overall globally, and in Mozambique-Africa. Recommendations for routine control and monitoring of MC will also be done since this hepatotoxin is not included in water control tests data in Mozambique. 


\section{Microcystin-Producing Species and Toxicology}

\subsection{Microcystin-Producing Species}

MCs are secondary metabolites produced by cyanobacteria species that occur naturally (but it can be increased severely by human activities) in freshwater environments. The most reported cyanobacteria species, which produce MCs are listed in Table 1 and include species of the families Microcystaceae, Nostocaceae, Microcoleaceae, Oscillatoriaceae, Pseudanabaenaceae (Table 1). The occurrence and development of a particular genus and species of cyanobacteria and cyanotoxins production worldwide seem to be conditioned to water chemistry and climate conditions [8]. In a temperate climate, Microcystis and Anabaena blooms occur widely while Cylindrospermopsis develops in tropical regions [9]. There are toxic and non-toxic cyanobacteria of the same species, which may be found together $[8,10,11]$. Toxic cyanobacteria can produce several toxins with different toxicity making it uncertain to assess the overall toxicity of bloom due to the variations of toxins concentration spatially and seasonally [12]. To distinguish toxic and non-toxic cyanobacteria species is very complicated, and consequently, the methods used are also complex. It implicates that the prevention of cyanobacteria bloom development is a suitable way to control toxic blooms $[13,14]$.

Table 1. Microcystin-producing species detected in freshwater bodies.

\begin{tabular}{|c|c|c|}
\hline Order & Family & Species \\
\hline Chroococcales & Microcystaceae & $\begin{array}{c}\text { Microcystis sp. [15], M. aeruginosa [16-26], M. viridis [20,24], } \\
\text { M. wesenbergii [25,27], M. spp. [28,29], M. ichthyoblabe [25] } \\
\text { and Synechocystis sp. [25] }\end{array}$ \\
\hline Nostocales & Nostocaceae & $\begin{array}{l}\text { Anabaena spp. [29,30], A. flos-aquae [23,27], A. sp. [15,31], } \\
\text { A. subcylindrica [32], A, variables [32], Nostoc sp. [27], } \\
\text { Aphanizomenon flos-aquae }[23,29,33] \text { and A. circinalis [34] }\end{array}$ \\
\hline \multirow[b]{2}{*}{ Oscillatoriales } & Microcoleaceae & Planktothrix prolifica [24] and P. agardhii [29] \\
\hline & Oscillatoriaceae & $\begin{array}{c}\text { Oscillatoria agardhii [35], O. limosa [36], O. chlorina [25], } \\
\text { Phormidium konstantinosum (O. tenuis) [36], P. corium [32] } \\
\text { and Plectonema boryanum [32] }\end{array}$ \\
\hline \multirow{2}{*}{ Synechococcales } & Merismopediaceae & Synechocystis aquatilis f. salina [37] and Aphanocapsa cumulus [38] \\
\hline & Pseudanabaenaceae & Pseudanabaena mucicola [25] and P. galeata [25] \\
\hline
\end{tabular}

The factors that promote the MC synthesis are not yet clearly understood, however, the optimal growth of MC-producing species and toxicity seem influenced by light intensity, nutrients, and temperature, among other factors. For example, the higher toxicity of $M$. aeruginosa extracts was verified in extreme $\mathrm{pH}$ values [39,40], and heavy metals such as Zinc and Iron did not influence the M. aeruginosa toxicity [41]. The content of nitrogen and phosphorus influenced the toxicity of $M$. aeruginosa extracts. Low nitrogen content reduces the $M$. aeruginosa toxicity, while low phosphorous increased the toxicity in the natural population $[42,43]$ and reduced in lab experiments $[16,21,44,45]$. Another lab conclusion was the correlation of colony size and content of toxic cyclic heptapeptide of the non-axenic strain of $M$. viridis and axenic $M$. viridis was also verified [20,46,47]. In general, the optimal temperature for which MC-producing species produce MC ranged from 20 to $25{ }^{\circ} \mathrm{C}$ [21,40,48,49]. This range of optimal temperature suggests that cyanobacteria blooms are most toxic during periods with warm weather and in areas with warm climates [8].

\subsection{Toxicology}

Microcystins (Figure 2) are the largest diverse group of cyanobacterial toxins, and to date, more than $240 \mathrm{MCs}$ analogs are known, and they vary structurally in terms of the degree of methylation, hydroxylation, epimerization, peptide sequence, and consequently in their toxic effects [50-52]. Chemically, MC is a group of monocyclic heptapeptides (numbered in Figure 2) containing both D- 
and L-amino acids plus N-methyldehydroalanine (Mdha) and a unique $\beta$-amino acid side-group, 3-amino-9-methoxy-2-6,8-trymethyl-10-phenyldeca-4,6-dienoic acid (Adda) and their analogs differ among them, at the two L-amino acids and on the methyl groups on D-erythro- $\beta$-methylaspartic acid (D-MeAsp) and Mdha with molecular weight varying from 900 to 1100 Daltons. MC-LR, MC-RR, and MC-YR are common MC variants, the letters $\mathrm{L}, \mathrm{R}$, and $\mathrm{Y}$ represent the aminoacids leucine, arginine, and tyrosine, which appear on the MC molecule in different combinations [50,53-58] being MC-LR the most studied. The biosynthesis of this group of cyanotoxin is regulated by non-ribosomal peptide synthetase and polyketide synthase domains, being $M C y S$ the gene cluster, which has been sequenced and partially characterized in several cyanobacterial species of the family Microcystaceae, Nostocaceae, Microcoleaceae, Oscillatoriaceae, Merismopediacea, and Pseudanabaenacea [16-38,59,60]

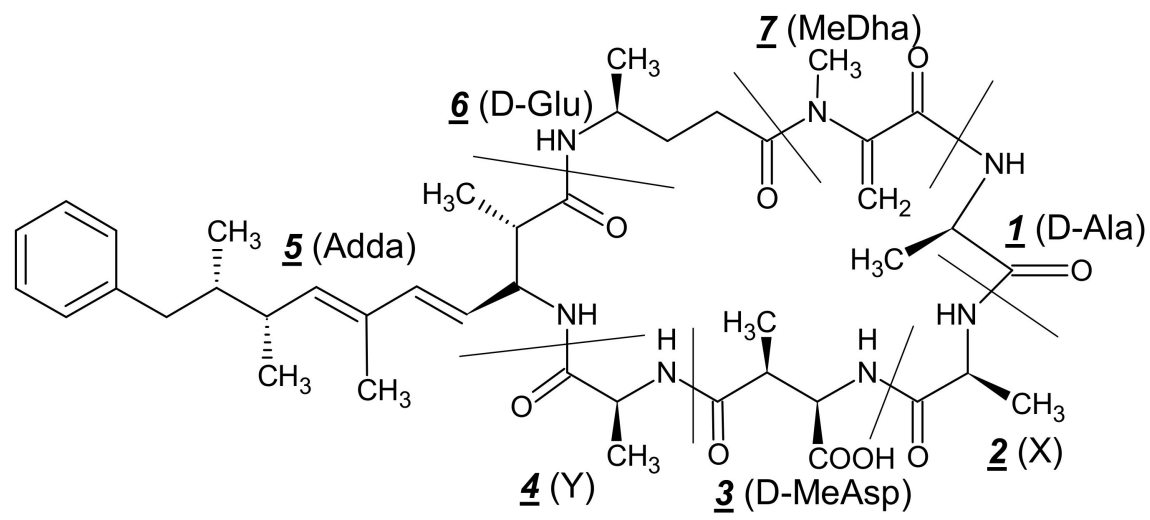

Figure 2. General chemical structure of microcystins. The common MC variant is MC-LR when $X$ and Y correspond to L-Leu and L-Arg.

The mechanism of MCs toxicity seems to be well understood. They bind to serine/threonine-specific protein phosphatases (PPs) such as PP1 and PP2A, inhibiting their activity [61-63]. Adda moiety (Figure 1) plays an important role in the MC toxicity group since its isomerization and/or oxidation reduces the toxicity $[64,65]$. The inhibition of PP1and PP2A as a result of MC acute exposure causes excessive protein phosphorylation, alterations in the cytoskeleton, loss of cell shape, and consequently destruction of liver cells leading to intrahepatic hemorrhage or hepatic insufficiency [58]. Oxidative stress increasing in cells and consequent apoptosis, which can cause tumor promotion, is another mechanism of MC toxicity [66-68].

\section{Effects of Microcystin in Humans, Symptoms, and Treatment}

Microcystin effects in humans depend on the time of exposure and concentration ingested [69], and the studies are based on epidemiologic data but the reported studies on laboratory animals. Human health problems are mostly caused by chronic exposure by consumption of contaminated water or food, dermal exposure, or inhalation [57]. MC human poisoning episodes were reported in different parts of the world after the consumption of contaminated water or during sport or recreational activities [59,70-72]. Some examples of MC human poisoning cases are described; America-in 1996, an episode of human intoxications by MC was reported in Brazil with more than 76 deaths of patients at two dialysis centers in Caruaru. The municipal water supplied to the dialysis centers was the source of MC [71,73-75]. In Argentina, a human poisoning caused by MC involving a young man after immersion in an intense bloom Microcystis sp lake during sport and recreational activities were recorded. Four hours after exposure, the patient showed nausea, abdominal pain, and fever, and $48.6 \mu \mathrm{g} \cdot \mathrm{L}^{-1}$ of microcystin-LR was detected in the water samples [76]. Other cases were recorded in Uruguay (January 2015) involving a 20-month-old child and her family during recreational activities. These victims were admitted to the hospital with diarrhea, vomiting, fatigue, and jaundice and the analysis confirmed the presence of MC-LR $\left(2.4 \mathrm{ng} \cdot \mathrm{g}^{-1}\right.$ tissue) and [D-Leu1]MC-LR (75.4 ng. $\mathrm{g}^{-1}$ tissue) explanted liver [77]. Africa-toxic cyanobacteria suspected intoxication cases were reported in 
Zimbabwe involving children that were hospitalized in the Hospital of Harare with gastroenteritis symptoms [78]. In Europe-121 people presented abdominal pain, nausea, vomiting, diarrhea, fever, headaches, and muscle pain after consumption of untreated water from the River Kavlingean in Sweden. In this case a bloom of MC-producing such as Planktothrix agardhii and Microcystis spp. was observed in the river [79]. The most affected human organ is the liver [57]. However, in vivo and in vitro studies indicated that the kidney and colon are also affected [80-85]. The symptoms generally reported in humans due to the $\mathrm{MC}$ intoxication include gastroenteritis and related diseases, allergic and irritation reactions, liver diseases, tumors, and primary liver cancer and colorectal cancers, and massive hepatic hemorrhage. MC human poisoning treatment is very complicated due to the rapid, irreversible, and severe liver damage [86], however, gastric lavage [87], administration of monoclonal antibodies against MC-LR [88], immunosupressant Cyclosporine A, antibiotic rifampin [89], and membrane-active antioxidant vitamin E, taken as a dietary supplement [90] are recommended.

\section{Microcystin Detection and Monitoring in Freshwater}

According to the World Health Organization (WHO) guideline, the permitted limit of MC-LR for drinking water is $1.0 \mu \mathrm{g} \cdot \mathrm{L}^{-1}$, and the tolerable daily intake is $0.04 \mu \mathrm{gKg}^{-1}$ [91]. There are several MC detection methods, the most reported are listed in Table 2. Immunoassays (IA) are suitable methods of MC detection in Mozambique because they do not require sophisticated laboratory equipment and have a limit of detection below the maximum limit $\left(1 \mu \mathrm{g} \cdot \mathrm{L}^{-1}\right)$. Additionally, IA can be used in both laboratory and field studies.

Table 2. MC detection methods in drinking water. IA-immunoassays, HPLC—high-performance liquid chromatographic, PAD—photodiode-array detector, LC—liquid chromatography, MS—mass spectroscopy, MALDI-TOF MS-matrix-assisted laser desorption/ionization time-of-flight mass spectrometry, UV-ultraviolet detector.

\begin{tabular}{ccccc}
\hline MC Variant & Detection & LOD & LOQ & Reference \\
\hline $\begin{array}{c}\text {-LR: -LY: -LW: -LF: -LA: } \\
\text { Asp }^{3} \text { (Z)-Dhb }- \text {-HtyR: -DAsp }- \text { RR }\end{array}$ & IA & $50-20,000 \mathrm{pg} \cdot \mathrm{mL}^{-1}$ & & {$[88,92-102]$} \\
\hline -RR: -LR: -LY: -LF & HPLC-UV & & {$[102]$} \\
\hline -RR: -LR: -LY: -LW: -LF: -FR; -WR & HPLC-PAD & $5 \mathrm{ng}$ & {$[103,104]$} \\
\hline $\begin{array}{c}\text { 3-demethyl-MC-LR: -LR: -LY: -LA: } \\
\text {-LW: -LF: 3-demethyl-MC-RR: -RR: } \\
\text { 3-demethyl-MC-YR: -YR }\end{array}$ & LC-MS (/MS) & $0.2 \mathrm{pg}-2057 \mathrm{pg}$ & $1 \mathrm{pg}-15 \mu \mathrm{gg}^{-1}$ & {$[93,102,104-108]$} \\
\hline $\begin{array}{c}\text { D-MC-LR; -LR: D-MC-RR: D-MC-YR: } \\
\text {-RR: -YR: [H4]MC-YR: -WR }\end{array}$ & MALDI-TOF MS & & & \\
\hline
\end{tabular}

\section{The Occurrence of Microcystin in Mozambican Drinking Water}

\subsection{The Drinking Water Scenario in Mozambique}

The drinking water supply scenario in Mozambique still faces major challenges because a majority of the population still consumes untreated drinking water and consequently is exposed to many water-borne diseases. Only $50 \%$ of the population has access to "safe drinking water". Urban areas are the most favored, with $80 \%$, while rural and most of the population have only $35 \%$ coverage and consume untreated water daily from rivers, lakes, and small puddles that form after or during the raining season [5,7]. The low water supply cover in Mozambique is inconceivable due to several reasons, among them, the existence of natural water cover (rivers) in the whole country and the presence of excessive fragmentation of governmental organisms for water management (Figure 1). The water management is led by the Ministry of Public Works, Habitation and Hydric Resources (MOPHRH), which operates, among others, with the National Direction of Water Supply and Sanitation, National Direction of Hydric Resource Management, Water Regional Administrations, Sanitation, and Water Supply Infra-structure Administration, Water Regulation Council, Fund for Investment 
and Patrimony of Water Supply, and other private institutions, which provide goods and services. In order to improve the water management and expand the coverage, different projects funded by the Mozambican government and non-governmental organizations such as Plataforma Moçambicana de Água [6], Greater Maputo Water Supply Expansion Project [110], Integrated Water Supply and Sanitation Project for the provinces of Niassa and Nampula [111], National Rural Water Supply and Sanitation Program (PRONASAR) in Nampula and Zambezia Provinces [112], Inhambane Rural Water Supply and Sanitation Program [113], and others were implemented involving all the MOPHRH, civil society, and private organisms. However, still to date, the national water supply does not cover enough, with the population still consuming untreated water.

The water policy in Mozambique was approved in 1995, revised in 2007 and 2016, which, in the scope of water supply and sanitation, has the following relevant goals [114]:

- Achieve the sustainable development goals, universal access to water supply, and sanitation.

- Meeting of the basic needs of the poorest population, to reduce poverty, always looking for a sustainability situation.

- Water valuing, not only as a social and environmental asset but also with the economic value it holds.

- Government's concentration on the definition of priorities, standards, regulation, and promotion of the private sector.

- Development of an institutional framework that contributes to the management of water as a resource and provision of decentralized and autonomous water supply and sanitation, where the private sector is called upon to participate.

The Ministry of Health (MH) is the legal organism responsible for water quality control and follows the regulation of the WHO, which sets the parameters of the quality of water intended for human consumption and the methods of carrying out their checks in order to protect human health. The water quality control recommended by WHO include MC among other biological parameter and the provisional guideline value is $1 \mu \mathrm{g} \cdot \mathrm{L}^{-1}$ for drinking water [115]. The challenge is enormous in Mozambique for control or monitoring of this hepatotoxin due to the lack of adequate laboratories for the detection of $\mathrm{MC}$ in drinking water, even for $50 \%$ of the population that consumes treated water. This scenario shows clearly that all the Mozambican population is very vulnerable to MC exposure.

\subsection{Microcystin in Mozambican Drinking Water}

The drinking water is supplied by private (autonomous systems) and governmental operators. In Table 3, are listed the main sources of drinking water in Mozambique and includes underground and water river. The drinking water treatment is performed mainly by disinfection with chlorine, but is some regions such as Pemba and Niassa, the water treatment system includes the removal of iron by aeration. Not only is there no drinking water treatment for $\mathrm{MC}$ removal, but also MC incidence data in Mozambique are very limited. However, according to the WHO, more than 500,000 cases of diarrhea were reported, which 100 and 7 cases correspond to dysentery and cholera, respectively, and others are unknown [116]. 
Table 3. Treatment and drinking water supply in Mozambique. Gov—Government system. HTH—High test hypochlorite [7,114].

\begin{tabular}{|c|c|c|c|c|c|}
\hline Province & Water System & Water Treatment Center & Capacity, $\mathrm{m}^{3} \cdot \mathrm{dia}^{-1}$ & Water Source & Supplied Sites \\
\hline \multirow{4}{*}{ Maputo } & Gov-Umbeluzi & Umbeluzi & 240,000 & $\begin{array}{c}\text { Umbeluzi river and } \\
\text { Pequenos Limbobo Dam }\end{array}$ & Maputo, Matola and Boane \\
\hline & Ka Tembe Autonomous & Ka Tembe & 760 & Underground - Ka Tembe & Ka Tembe \\
\hline & Vila Olimpia Autonomous & & - & Underground - Maputo & Vila Olimpia \\
\hline & The Small & & 6500 & Underground -Maputo & $\begin{array}{l}\text { Zona Verde, Kongolote, Matola Gare } \\
\text { na Matola, Magoanine and Albazine }\end{array}$ \\
\hline \multirow{7}{*}{ Gaza } & Gov-Xai-Xai & & & & Bairro 11, Bairro 13, Hospital, Patrice \\
\hline & Gov-Limpopo & Xai-Xai & 22,790 & Limpopo river & $\begin{array}{l}\text { Lumumba, Inhamissa 6, CFPP, } \\
\text { Marieny Gouaby, Chinuguine }\end{array}$ \\
\hline & Gov-Chongoene & & & & and Praia \\
\hline & Xai-Xai Autonomous & & & Underground - Xai-Xai & $\begin{array}{l}\text { Chicumbane, Julius Nyerere, } \\
\text { Muahetane e Chongoene }\end{array}$ \\
\hline & Gov-Chókwè & & 10,056 & $\begin{array}{l}\text { Limpopo river and } \\
\text { underground - Chokwe }\end{array}$ & \multirow{2}{*}{$\begin{array}{c}\text { Lionde, Conhane, Massavassa, } \\
\text { Nwachicoluane, Xilembene, } \\
\text { Hókwe, Mapapa }\end{array}$} \\
\hline & Chókwè Autonomous & & 6816 & & \\
\hline & Gov-Guija & & & Underground - Guija & vila-sede do distrito de Guijá \\
\hline \multirow{3}{*}{ Inhambane } & Gov-Inhambane & & 11,176 & & $\begin{array}{l}\text { Inhambane City, Salela, Nhamua e } \\
\text { Josina Machel }\end{array}$ \\
\hline & Gov-Maxixi & & 9120 & Inhanombe river & $\begin{array}{c}\text { Chambone, Rumbana, Nhambiho, } \\
\text { Bato, Habana, Malalane, Macupula, } \\
\text { Macuamene, Maquetela, Eduardo } \\
\text { Mandlane, Nhamaxaxa, Matadouro, } \\
\text { Mabil, Barrane and Bembe }\end{array}$ \\
\hline & Mangapana and Mabil Autonomous & & & & Mangapana and Mabil \\
\hline Sofala & Beira and Dondo & Mutua & 50,000 & Pungué river & Beira and Dondo \\
\hline Manica & Gov-Manica & Chicamba & 38,600 & & $\begin{array}{l}\text { Manica, Chimoio and Gondola and } \\
\text { Messica and Bandula village }\end{array}$ \\
\hline \multirow[t]{2}{*}{ Tete } & Gov-Tete & $\begin{array}{l}\text { Tete: Aeration through a cascade, } \\
\text { followed by two decantation tanks } \\
\text { and then filtration and finally } \\
\text { disinfection with granular chlorine }\end{array}$ & 38,495 & Zambeze river & Tete city \\
\hline & The Degué small & & & & Degué \\
\hline Zambezia & Gov-Zambezia & Licuar: Disinfection with HTH & 19,512 & Underground - Licuar & Quelimane, Nicoadala and Licuar \\
\hline
\end{tabular}


Table 3. Cont.

\begin{tabular}{|c|c|c|c|c|c|}
\hline Province & Water System & Water Treatment Center & Capacity, $\mathrm{m}^{3} \cdot \mathrm{dia}^{-1}$ & Water Source & Supplied Sites \\
\hline \multirow{2}{*}{ Nampula } & Gov-Nampula & $\begin{array}{l}\text { Nampula: Pre-chlorination, } \\
\text { flocculation, decanting and } \\
\text { filtration }\end{array}$ & 20,000 & Monapo dam & Nampula city \\
\hline & Gov-Nacala & $\begin{array}{l}\text { Nacala: A mixture of flocculation, } \\
\text { decantation, filtration, } \\
\text { and disinfection }\end{array}$ & 6000 & Nacala dam & Nacala city \\
\hline \multirow{2}{*}{$\begin{array}{l}\text { Cabo } \\
\text { Delgado }\end{array}$} & Gov-Pemba & $\begin{array}{l}\text { Pemba: Removal of iron by } \\
\text { aeration and filtration }\end{array}$ & 12,000 & Underground-Metuge & Pemba city \\
\hline & Gov-Angoche & Angoche: Disinfection with HTH & 1800 & Underground-Malatane & Angoche \\
\hline \multirow{3}{*}{ Niassa } & Gov-Lichinga & Locumué & 2400 & Locumué dam & Lichinga \\
\hline & Chiuaula Autonomous & & & Underground - Chiuala & Chiuaula \\
\hline & Cuamba & Cuamba: Disinfection with HTH & 960 & Mpopole dam & Cuamba \\
\hline
\end{tabular}


These data indicate that many people of Mozambique consume food and water unsafely. Few studies (Figure 1) were done by Pedro et al. [117-119] and Bojcevska and Jergil [120] in Pequenos Libombos dam, Nhambavale lake, Chòkwé irrigation channels and Chidenguele sites in the South of Mozambique during 2003, 2008, and 2009 and their studies indicated the occurrence of MC-LR, -YR, and -RR produced by Microcystis sp. (M. novacekii, botrys and other) and Cylindrospermopsis raciborskii [117-120] (Table 4). MC concentration varies from less than 0.01 (below quantification levels) to 0.02 in Pequenos Libombos dam, less to 0.01 to 0.68 in Chòkwé irrigation channels, 0.86 to 7.82 in Nhambavale lake and 0.57 to $6.83 \mu \mathrm{g} \cdot \mathrm{L}^{-1}$ in Chidenguele. Higher MC concentration values than the maximum limit ranging from 6.83 to $7.78 \mu \mathrm{g} \cdot \mathrm{L}^{-1}$ (around 7 times above) were found in the Nhambavale lake and Chidenguele sites. These data highlight (suggest) the need to implement an operational monitoring program of MCs since the tests recommended by $\mathrm{MH}$ do not include the MC test [121]. Neighboring countries published other data, which support the need for MC monitoring in Mozambique (Figure 1), namely:

- South Africa: MC Producers: Synechocystis sp. Microcystis aeruginosa, Microcystis panniformis, Nostoc sp., Planktothrix sp., Phormidium sp., in the Limpopo river basin [122-126], Hartbeespoort dam [127-131], Kruger National Park [132], Sand, Mawoni, Lephalale, Mokolo, Crocodile, Nzhelele ivers [126] MC -YR, -LR, -FR, -YA, -LA, -LAba (0.156-0.270, 0.059-0.18, 0.09, 0.02-0.044, 0.051-0.241, $0.080 \mathrm{mg} \cdot \mathrm{g}^{-1}$ ) in Natal and Transvaal dams [133], $8.6 \mu \mathrm{g} \cdot \mathrm{L}^{-1}$ in Hartbeespoort dam [134], $12,300 \mu \mathrm{g} \cdot \mathrm{L}^{-1}$ in Hartbeespoort lake [135].

- Tanzania: MC-LR and -RR in different tissues of dead flamingos (Phoeniconaias minor) from Empakai Crater, Lake Natron and Lake Manyara (0.165-1.16 ng.g $\left.{ }^{-1}\right)$ [136-138], MC-RR (0.4-13 $\left.\mu \mathrm{gL}^{-1}\right)$ in Victoria lake [139,140], MC producers: Aphanocapsa sp., Anabaena sp., Microcystis sp. In Victoria lake [139,140].

- Zimbabwe: MC producers: Microcystis aeruginosa in Mzingwane river, Shashe River [126], Microcystis wesenbergii [141,142]. MC-LR $\left(1.62-22 \mu \mathrm{gL}^{-1}\right)$ in Chivero lake [141,142].

- Malawi: MC producers: Anabaena sp. In Malawi lake [143]. 
Table 4. The Incidence of Microcystin and its producers in the aquatic environments of Mozambique. PL-Pequenos Libombos dam, NL-Nhambavale lake, $\mathrm{CH}$-Chòkwé irrigation channels, RFLP—restriction fragment length polymorphism, MC—microcystins, ELISA—enzyme-linked immunosorbent assay, CG-Chidengule, LM-light microscope, PCR - polymerase chain reaction, ML-Malawi lake, NL— Niassa lake.

\begin{tabular}{|c|c|c|c|c|c|c|c|}
\hline \multirow{2}{*}{ Local } & \multirow{2}{*}{ Date } & \multicolumn{2}{|c|}{ Producer } & \multicolumn{3}{|c|}{ MC } & \multirow[t]{2}{*}{ Reference } \\
\hline & & Species & Detection & MC Variant & Detection & Conc. & \\
\hline \multirow{4}{*}{ PL } & \multirow{12}{*}{ 2008-2009 } & Microcystis sp. & PC gene & \multirow{4}{*}{ LR and YR } & & \multirow{4}{*}{$3.9 \mathrm{ng} \cdot \mathrm{g}^{-1}$} & \\
\hline & & Microcystis sp. & MCyA-MISY gene & & & & \\
\hline & & Microcystis sp. & MCyB gene & & & & \\
\hline & & Microcystis sp. & RFLP & & & & \\
\hline \multirow{4}{*}{ NL } & & Microcystis sp. & PC gene & \multirow{4}{*}{ LR, YR and RR } & \multirow{8}{*}{ LC-MS } & \multirow{4}{*}{$159.4 \mathrm{ng} \cdot \mathrm{g}^{-1}$} & \\
\hline & & Microcystis sp. & MCyA-MISY gene & & & & [118] \\
\hline & & Microcystis sp. & MCyB gene & & & & \\
\hline & & Microcystis sp. & RFLP & & & & \\
\hline \multirow{4}{*}{$\mathrm{CH}$} & & Microcystis sp. & PC gene & \multirow{4}{*}{ LR } & & \multirow{4}{*}{$2.7 \mathrm{ng} \cdot \mathrm{g}^{-1}$} & \\
\hline & & negative & MCyA-MISY gene & & & & \\
\hline & & negative & MCyB gene & & & & \\
\hline & & negative & RFLP & & & & \\
\hline PL & \multirow{3}{*}{2002} & & \multirow{3}{*}{ LM } & \multirow{3}{*}{$\mathrm{MC}$} & \multirow{3}{*}{ ELISA } & $0.22 \mu \mathrm{g} \cdot \mathrm{L}^{-1}$ & \\
\hline $\mathrm{CH}$ & & Cylindrospermopsis raciborskii & & & & $<0.01 \mu \mathrm{g} \cdot \mathrm{L}^{-1}$ & {$[120]$} \\
\hline CG & & Microcystis novacekii and M. botrys & & & & $6.83 \mu \mathrm{g} \cdot \mathrm{L}^{-1}$ & \\
\hline \multirow{2}{*}{ PL } & \multirow{7}{*}{ 2008-2009 } & & & LR & \multirow{7}{*}{ LC-MS } & $<0.01 \mu \mathrm{g} \cdot \mathrm{L}^{-1}$ & \\
\hline & & & & YR & & $0.01 \mu \mathrm{g} \cdot \mathrm{L}^{-1}$ & \\
\hline \multirow{2}{*}{$\mathrm{CH}$} & & & & LR & & $0.68 \mu \mathrm{g} \cdot \mathrm{L}^{-1}$ & \\
\hline & & & & YR & & $0.06 \mu \mathrm{g} \cdot \mathrm{L}^{-1}$ & [117] \\
\hline \multirow{3}{*}{ NL } & & & & LR & & $7.78 \mu \mathrm{g} \cdot \mathrm{L}^{-1}$ & \\
\hline & & & & YR & & $0.07 \mu \mathrm{g} \cdot \mathrm{L}^{-1}$ & \\
\hline & & & & RR & & $<0.01 \mu \mathrm{g} \cdot \mathrm{L}^{-1}$ & \\
\hline
\end{tabular}


Table 4. Cont.

\begin{tabular}{|c|c|c|c|c|c|c|c|}
\hline \multirow{2}{*}{ Local } & \multirow{2}{*}{ Date } & \multicolumn{2}{|c|}{ Producer } & \multicolumn{3}{|c|}{ MC } & \multirow[t]{2}{*}{ Reference } \\
\hline & & Species & Detection & MC Variant & Detection & Conc. & \\
\hline \multirow[b]{2}{*}{ PL } & \multirow{6}{*}{ 2008-2009 } & \multirow{6}{*}{ Microcystis aeruginosa } & PC gene & & & & \multirow{6}{*}{ [119] } \\
\hline & & & MCyB-Taq-Nuclease assay & & & & \\
\hline \multirow{2}{*}{ NL } & & & PC gene & & & & \\
\hline & & & MCyB-Taq-Nuclease assay & & & & \\
\hline \multirow{2}{*}{$\mathrm{CH}$} & & & PC gene & & & & \\
\hline & & & MCyB-Taq-Nuclease assay & & & & \\
\hline ML/NL & 2002 & Anabaena sp. & LM & & & & [143] \\
\hline NKP & 2007 & Microcystis aeruginosa & PCR & LR & ELISA & $23718 \mu \mathrm{g} \cdot \mathrm{L}^{-1}$ & [132] \\
\hline
\end{tabular}


For example, the drinking water in the Xai Xai district (Gaza province) (Figure 1) is supplied from the Limpopo river. This river contains different MC producers such as Synechocystis sp. Microcystis aeruginosa, Microcystis panniformis, Nostoc sp., Planktothrix sp., Phormidium sp., which were detected in South Africa areas [122-126]. The presence of a potentially toxic algae is not an indication of MC production but is an indication of the need for MC screening in order to confirm the MC presence.

\subsection{Removal of Microscystin from Drinking Water in Mozambique}

MCs can be removed from drinking water using several rapid and low-cost. The most are reported in laboratory studies, and they are not adaptable to economic conditions in Mozambique [144-150]. However, the following techniques seem to be useful in Mozambique and can be implemented in both rural and urban zones: Photolysis at 254 and $185 \mathrm{~nm}$ [147], use of wood-based and coconut-based activated carbons [148], use of bamboo-based charcoal adsorbent modified with chitosan [149], hydrophyte filter bed [150], biological activated carbon process [151], aquatic vegetable bed [152], and activated carbon from the seed husks of the pan-tropical tree, Moringa oleifera [153], among others.

\section{Final Considerations and Recommendations}

The drinking water supply scenario in Mozambique still faces major challenges because the majority of the population still consumes untreated drink water (from rivers, lakes, and small puddles that form after or during the raining season) and consequently exposed to many water diseases $[5,7]$ including, for example, gastroenteritis, which is caused by hepatotoxins MCs. To date, no data of water poisoning episodes recorded were associated with MCs presence in the water. However, this might be underestimated due to a lack of monitoring facilities and/or a lack of public health staff trained for recognizing symptoms of MCs intoxication since the presence of high MCs concentration was reported in Maputo and Gaza provinces. Few studies done in Maputo and Gaza provinces indicated the occurrence of MC-LR, -YR, and -RR at a concentration ranging from 6.83 to $7.78 \mu \mathrm{g} \cdot \mathrm{L}^{-1}$ [117-120], which are very high, around 7 times above the maximum limit $\left(1 \mu \mathrm{g} \cdot \mathrm{L}^{-1}\right)$ recommended by WHO [59]. The potential MC-producing in the studied sites is mostly Microcystis sp. [117-120]. However, MC distribution in Mozambique is unknown, and a monitoring program would help to understand the dimension of the problem. To date, no water MC poisoning episodes data recorded in Mozambique. The absence of MC intoxication episodes might be underestimated due to the absence of MC monitoring plan and/or a lack of public health staff trained in recognizing symptoms of MC intoxication. MC monitoring may be implemented according to recommendations of WHO [59] $\left(1 \mu \mathrm{g} \cdot \mathrm{L}^{-1}\right)$, and the respective MC analysis can be done in the existing water treatment centers in each province (Table 3). Rapid tests for MC detection, such as ELISA, can be used in each center. In the case of higher MCs content, some suitable techniques for MC removal may be used. The recommended techniques include photolysis at 254 and 185 [147], the use of wood-based and coconut-based activated carbons [148], use of bamboo-based charcoal adsorbent modified with chitosan [149], hydrophyte Filter Bed [150], Biological Activated Carbon Process [151], and aquatic vegetable bed [152], among others. These techniques can be used in both rural and urban areas due to their low-cost implementation and local access.

Author Contributions: Conceptualization, I.J.T.; introduction, I.J.T.; microcystin-producing species and toxicology, I.J.T.; effects of microcystin in humans, symptoms, and treatment, I.J.T.; microcystin detection and monitoring in freshwater, I.J.T.; the occurrence of Microcystin in Mozambican drinking water, I.J.T.; orientation, supervision and corrections, V.V. All authors have read and agreed to the published version of the manuscript.

Funding: This research was funded by Fundação para a Ciência e a Tecnologia (FCT) projects UIDB/04423/2020 and UIDP/04423/2020.

Acknowledgments: The authors acknowledge the Fundação Calouste Gulbenkian for the partial scholarship of Isidro José Tamele and the project EMERTOX [grant 734748], funded by H2020-MSCA-RISE 2016.

Conflicts of Interest: The authors declare no conflict of interest 


\section{References}

1. Moçambique INE Destaques. IV Censo 2017-Instituto Nacional de Estatistica-INE-Moçambique. Available online: http://www.ine.gov.mz/ (accessed on 26 November 2019).

2. Arndt, C.; Strzepeck, K.; Tarp, F.; Thurlow, J.; Fant, C.; Wright, L. Adapting to climate change: An integrated biophysical and economic assessment for Mozambique. Sustain. Sci. 2011, 6, 7-20. [CrossRef]

3. Strzepek, K.; Arndt, C.; Chinowsky, P.; Kuriakose, A.; Neumann, J.; Nicholls, R.; Thurlow, J.; Wright, L. Economics of Adaptation to Climate Change: Mozambique; World Bank: Washington, DC, USA, 2010.

4. Arndt, C.; Benfica, R.; Maximiano, N.; Nucifora, A.M.; Thurlow, J.T. Higher fuel and food prices: Impacts and responses for Mozambique. Agric. Econ. 2008, 39, 497-511. Available online: https:/www.unicef.org/evaldat abase/files/283729_B85_IOB_360_BW_WEB_Mozambique-Final.pdf (accessed on 22 May 2020). [CrossRef]

5. UNICEF; Government of the Netherlands Partnership for Water Supply S.a.H. Impact Evaluation of Drinking Water Supply and Sanitation Interventions in Rural Mozambique: More than Water; Printed Report; UNICEF: New York, NY, USA; Government of the Netherlands Partnership for Water Supply: The Hague, The Netherlands, 2011; Available online: https://www.unicef.org/evaldatabase/files/283729_B85_IOB_360_ BW_WEB_Mozambique-Final.pdf (accessed on 22 May 2020).

6. Ministério das Obras Públicas, Habitação e Recursos Hídricos. O Sector de Água em Moçambique. PLASMA-PLATAFORMA MOCAMBICANA DA AGUA; Ministério das Obras Públicas, Habitação e Recursos Hídricos: Maputo, Moçambique, 2016. Available online: https://plama.org.mz/index.php (accessed on 1 June 2020).

7. UNICEF. Situação da Água, Saneamento e Higiene em Moçambique; UNICEF: Maputo, Mozambique, 2017; Available online: https://www.unicef.org/mozambique/\%C3\%A1gua-saneamento-e-higiene (accessed on 1 June 2020).

8. World Health Organization. Cyanobacterial Toxins: Microcystin-LR in Drinking-Water: Background Document for Development of WHO Guidelines for Drinking-Water Quality; World Health Organization: Geneva, Switzerland, 2003.

9. Yoo, R.S. Cyanobacterial (Blue-Green Algal) Toxins: A Resource Guide; American Water Works Association: Denver, CO, USA, 1995.

10. Lawton, L.A.; Codd, G. Cyanobacterial (blue-green algal) toxins and their significance in UK and European waters. Water Environ. J. 1991, 5, 460-465. [CrossRef]

11. Skulberg, O.M.; Carmichael,W.W.; Codd, G.A.; Skulberg, R. Taxonomy of toxic Cyanophyceae (cyanobacteria). In Algal Toxins in Seafood and Drinking Water; Academic Press: New York, NY, USA, 1993; pp. 145-164.

12. Falconer, I.R.; Humpage, A.R. Health risk assessment of cyanobacterial (blue-green algal) toxins in drinking water. Int. J. Environ. Res. Public Health 2005, 2, 43-50. [CrossRef]

13. FerrÃo-Filho, A.S.; Azevedo, S.M.; DeMott, W.R. Effects of toxic and non-toxic cyanobacteria on the life history of tropical and temperate cladocerans. Freshw. Biol. 2000, 45, 1-19. [CrossRef]

14. Neilan, B.A.; Jacobs, D.; Blackall, L.L.; Hawkins, P.R.; Cox, P.T.; Goodman, A.E. rRNA sequences and evolutionary relationships among toxic and nontoxic cyanobacteria of the genus Microcystis. Int. J. Syst. Evol. Microbiol. 1997, 47, 693-697. [CrossRef]

15. Vaitomaa, J.; Rantala, A.; Halinen, K.; Rouhiainen, L.; Tallberg, P.; Mokelke, L.; Sivonen, K. Quantitative real-time PCR for determination of microcystin synthetase E copy numbers for Microcystis and Anabaena in lakes. Appl. Environ. Microbiol. 2003, 69, 7289-7297. [CrossRef]

16. Oh, H.-M.; Lee, S.J.; Jang, M.-H.; Yoon, B.-D. Microcystin production by Microcystis aeruginosa in a phosphorus-limited chemostat. Appl. Environ. Microbiol. 2000, 66, 176-179. [CrossRef]

17. Kotak, B.G.; Lam, A.K.Y.; Prepas, E.E.; Kenefick, S.L.; Hrudey, S.E. Variability of the hepatotoxin microcystin - LR in hypereutrophic drinking water lakes 1. J. Phycol. 1995, 31, 248-263. [CrossRef]

18. Zhao, G.; Wu, D.; Cao, S.; Du, W.; Yi, Y.; Gu, H. Efects of CeO2 Nanoparticles on Microcystis aeruginosa Growth and Microcystin Production. Bull. Environ. Contam. Toxicol. 2020, 104, 834-839. [CrossRef] [PubMed]

19. Utkilen, H.; Gjølme, N. Toxin production by Microcystis aeruginosa as a function of light in continuous cultures and its ecological significance. Appl. Environ. Microbiol. 1992, 58, 1321-1325. [CrossRef]

20. Watanabe, M.F.; Harada, K.-I.; Matsuura, K.; Watanabe, M.; Suzuki, M. Heptapeptide toxin production during the batch culture of two Microcystis species (Cyanobacteria). J. Appl. Phycol. 1989, 1, 161-165. [CrossRef] 
21. Watanabe, M.F.; Oishi, S. Effects of environmental factors on toxicity of a cyanobacterium (Microcystis aeruginosa) under culture conditions. Appl. Environ. Microbiol. 1985, 49, 1342-1344. [CrossRef] [PubMed]

22. Wicks, R.J.; Thiel, P.G. Environmental factors affecting the production of peptide toxins in floating scums of the cyanobacterium Microcystis aeruginosa in a hypertrophic African reservoir. Environ. Sci. Technol. 1990, 24, 1413-1418. [CrossRef]

23. Eynard, F.; Mez, K.; Walther, J.-L. Risk of cyanobacterial toxins in Riga waters (Latvia). Water Res. 2000, 34, 2979-2988. [CrossRef]

24. Willén, E.; Ahlgren, G.; Söderhielm, A.-C. Toxic cyanophytes in three Swedish lakes. Int. Ver. Für Theor. Und Angew. Limnol. Verh. 2000, 27, 560-564. [CrossRef]

25. Oudra, B.; Loudiki, M.; Vasconcelos, V.; Sabour, B.; Sbiyyaa, B.; Oufdou, K.; Mezrioui, N. Detection and quantification of microcystins from cyanobacteria strains isolated from reservoirs and ponds in Morocco. Environ. Toxicol. Int. J. 2002, 17, 32-39. [CrossRef]

26. Mankiewicz-Boczek, J.; Gagała, I.; Jurczak, T.; Urbaniak, M.; Negussie, Y.Z.; Zalewski, M. Incidence of microcystin-producing cyanobacteria in Lake Tana, the largest waterbody in Ethiopia. Afr. J. Ecol. 2015, 53, 54-63. [CrossRef]

27. Vasconcelos, V.; Sivonen, K.; Evans, W.; Carmichael, W.; Namikoshi, M. Hepatotoxic microcystin diversity in cyanobacterial blooms collected in Portuguese freshwaters. Water Res. 1996, 30, 2377-2384. [CrossRef]

28. Frank, C.A. Microcystin-producing cyanobacteria in recreational waters in southwestern Germany. Environ. Toxicol. Int. J. 2002, 17, 361-366. [CrossRef] [PubMed]

29. Henriksen, P. Toxic freshwater cyanobacteria in Denmark. In Cyanotoxins; Springer: Berlin/Heidelberg, Germany, 2001; pp. 49-56.

30. Rapala, J.; Sivonen, K. Assessment of environmental conditions that favor hepatotoxic and neurotoxic Anabaena spp. strains cultured under light limitation at different temperatures. Microb. Ecol. 1998, 36, 181-192. [CrossRef] [PubMed]

31. Rapala, J.; Sivonen, K.; Lyra, C.; Niemelä, S.I. Variation of microcystins, cyanobacterial hepatotoxins, in Anabaena spp. as a function of growth stimuli. Appl. Environ. Microbiol. 1997, 63, 2206-2212. [CrossRef]

32. Mohamed, Z.A.; El-Sharouny, H.M.; Ali, W.S. Microcystin production in benthic mats of cyanobacteria in the Nile River and irrigation canals, Egypt. Toxicon 2006, 47, 584-590. [CrossRef] [PubMed]

33. Maatouk, I.; Bouaïcha, N.; Fontan, D.; Levi, Y. Seasonal variation of microcystin concentrations in the Saint-Caprais reservoir (France) and their removal in a small full-scale treatment plant. Water Res. 2002, 36, 2891-2897. [CrossRef]

34. Vezie, C.; Brient, L.; Sivonen, K.; Bertru, G.; Lefeuvre, J.-C.; Salkinoja-Salonen, M. Variation of microcystin content of cyanobacterial blooms and isolated strains in Lake Grand-Lieu (France). Microb. Ecol. 1998, 35, 126-135. [CrossRef]

35. Sivonen, K. Effects of light, temperature, nitrate, orthophosphate, and bacteria on growth of and hepatotoxin production by Oscillatoria agardhii strains. Appl. Environ. Microbiol. 1990, 56, 2658-2666. [CrossRef]

36. Mez, K.; Beattie, K.A.; Codd, G.A.; Hanselmann, K.; Hauser, B.; Naegeli, H.; Preisig, H.R. Identification of a microcystin in benthic cyanobacteria linked to cattle deaths on alpine pastures in Switzerland. Eur. J. Phycol. 1997, 32, 111-117. [CrossRef]

37. Nascimento, S.M.; De Oliveira e Azevedo, S.M.F. Changes in cellular components in a cyanobacterium (Synechocystis aquatilis f. salina) subjected to different N/P ratios-An ecophysiological study. Environ. Toxicol. Int. J. 1999, 14, 37-44. [CrossRef]

38. Domingos, P.; Rubim, T.; Molica, R.; Azevedo, S.; Carmichael, W. First report of microcystin production by picoplanktonic cyanobacteria isolated from a northeast Brazilian drinking water supply. Environ. Toxicol. Int. J. 1999, 14, 31-35. [CrossRef]

39. Carmichael, W. The Water Environment: Algal Toxins and Health; Springer Science \& Business Media: Berlin/Heidelberg, Germany, 2013.

40. Song, L.; Sano, T.; Li, R.; Watanabe, M.M.; Liu, Y.; Kaya, K. Microcystin production of Microcystis viridis (cyanobacteria) under different culture conditions. Phycol. Res. 1998, 46, 19-23. [CrossRef]

41. Lukač, M.; Aegerter, R. Influence of trace metals on growth and toxin production of Microcystis aeruginosa. Toxicon 1993, 31, 293-305. [CrossRef] 
42. Rinta-Kanto, J.M.; Konopko, E.A.; DeBruyn, J.M.; Bourbonniere, R.A.; Boyer, G.L.; Wilhelm, S.W. Lake Erie Microcystis: Relationship between microcystin production, dynamics of genotypes and environmental parameters in a large lake. Harmful Algae 2009, 8, 665-673. [CrossRef]

43. Te, S.H.; Gin, K.Y.-H. The dynamics of cyanobacteria and microcystin production in a tropical reservoir of Singapore. Harmful Algae 2011, 10, 319-329. [CrossRef]

44. Codd, G. Cyanobacterial toxins. In Biochemistry of the Algae and Cyanobacteria; Oxford University Press: Oxford, UK, 1988; pp. 283-296.

45. Orr, P.T.; Jones, G.J. Relationship between microcystin production and cell division rates in nitrogen-limited Microcystis aeruginosa cultures. Limnol. Oceanogr. 1998, 43, 1604-1614. [CrossRef]

46. Jungmann, D.; Ludwichowski, K.U.; Faltin, V.; Benndorf, J. A field study to investigate environmental factors that could effect microcystin synthesis of a Microcystis population in the Bautzen reservoir. Ienternationale Rev. Der Gesamten Hydrobiol. Und Hydrogr. 1996, 81, 493-501. [CrossRef]

47. Kaya, K.; Watanabe, M.M. Microcystin composition of an axenic clonal strain of Microcystis viridis and Microcystis viridis-containing water blooms in Japanese freshwaters. J. Appl. Phycol. 1990, 2, 173-178. [CrossRef]

48. Van der Westhuizen, A.; Eloff, J. Effect of temperature and light on the toxicity and growth of the blue-green alga Microcystis aeruginosa (UV-006). Planta 1985, 163, 55-59. [CrossRef] [PubMed]

49. Gorham, P.R. Toxic algae. In Algae and Man; Springer: Berlin/Heidelberg, Germany, 1964; pp. 307-336.

50. Bartram, J.; Chorus, I. Toxic Cyanobacteria in Water: A Guide to Their Public Health Consequences, Monitoring and Management; CRC Press: Boca Raton, FL, USA, 1999.

51. Welker, M.; Von Döhren, H. Cyanobacterial peptides-nature's own combinatorial biosynthesis. FEMS Microbiol. Rev. 2006, 30, 530-563. [CrossRef] [PubMed]

52. Svirčev, Z.; Drobac, D.; Tokodi, N.; Mijović, B.; Codd, G.A.; Meriluoto, J. Toxicology of microcystins with reference to cases of human intoxications and epidemiological investigations of exposures to cyanobacteria and cyanotoxins. Arch. Toxicol. 2017, 91, 621-650. [CrossRef] [PubMed]

53. Botes, D.P.; Wessels, P.L.; Kruger, H.; Runnegar, M.T.; Santikarn, S.; Smith, R.J.; Barna, J.C.; Williams, D.H. Perkin Transactions 1. Structural studies on cyanoginosins-LR,-YR,-YA, and-YM, peptide toxins from Microcystis aeruginosa. J. Chem. Soc. Perkin Trans. 1 1985, 2747-2748. [CrossRef]

54. Namikoshi, M.; Yuan, M.; Sivonen, K.; Carmichael, W.W.; Rinehart, K.L.; Rouhiainen, L.; Sun, F.; Brittain, S.; Otsuki, A. Seven new microcystins possessing two L-glutamic acid units, isolated from Anabaena sp. strain 186. Chem. Res. Toxicol. 1998, 11, 143-149. [CrossRef]

55. Rinehart, K.L.; Namikoshi, M.; Choi, B.W. Structure and biosynthesis of toxins from blue-green algae (cyanobacteria). J. Appl. Phycol. 1994, 6, 159-176. [CrossRef]

56. Sivonen, K. Cyanobacterial toxins and toxin production. Phycologia 1996, 35, 12-24. [CrossRef]

57. Campos, A.; Vasconcelos, V. Molecular mechanisms of microcystin toxicity in animal cells. Int. J. Mol. Sci. 2010, 11, 268-287. [CrossRef]

58. Prieto, A.I.; Jos, A.; Pichardo, S.; Moreno, I.; de Sotomayor, M.Á.; Moyano, R.; Blanco, A.; Cameán, A.M. Time-dependent protective efficacy of Trolox (vitamin E analog) against microcystin-induced toxicity in tilapia (Oreochromis niloticus). Environ. Toxicol. Int. J. 2009, 24, 563-579. [CrossRef]

59. World Health Organization. Guidelines for Drinking-Water Quality [Electronic Resource]: Incorporating First Addendum. Vol. 1, Recommendations; Springer: Geneva, Switzerland, 2006.

60. Tillett, D.; Dittmann, E.; Erhard, M.; Von Döhren, H.; Börner, T.; Neilan, B.A. Structural organization of microcystin biosynthesis in Microcystis aeruginosa PCC7806: An integrated peptide-polyketide synthetase system. Chem. Biol. 2000, 7, 753-764. [CrossRef]

61. Van Apeldoorn, M.E.; Van Egmond, H.P.; Speijers, G.J.; Bakker, G.J. Toxins of cyanobacteria. Mol. Nutr. Food Res. 2007, 51, 7-60. [CrossRef]

62. MacKintosh, C.; Beattie, K.A.; Klumpp, S.; Cohen, P.; Codd, G.A. Cyanobacterial microcystin-LR is a potent and specific inhibitor of protein phosphatases 1 and 2A from both mammals and higher plants. FEBS Lett. 1990, 264, 187-192. [CrossRef]

63. Gulledge, B.; Aggen, J.; Huang, H.; Nairn, A.; Chamberlin, A. The microcystins and nodularins: Cyclic polypeptide inhibitors of PP1 and PP2A. Curr. Med. Chem. 2002, 9, 1991-2003. [CrossRef] [PubMed] 
64. Song, W.; De La Cruz, A.A.; Rein, K.; O'Shea, K.E. Ultrasonically induced degradation of microcystin-LR and-RR: Identification of products, effect of $\mathrm{pH}$, formation and destruction of peroxides. Environ. Sci. Technol. 2006, 40, 3941-3946. [CrossRef] [PubMed]

65. Tsuji, K.; Naito, S.; Kondo, F.; Ishikawa, N.; Watanabe, M.F.; Suzuki, M.; Harada, K.-I. Stability of microcystins from cyanobacteria: Effect of light on decomposition and isomerization. Environ. Sci. Technol. 1994, 28, 173-177. [CrossRef] [PubMed]

66. Zhang, H.; Zhang, J.; Chen, Y.; Zhu, Y. biochemistry. Microcystin-RR induces apoptosis in fish lymphocytes by generating reactive oxygen species and causing mitochondrial damage. Fish Physiol. 2008, 34, 307-312.

67. Fujiki, H.; Suganuma, M. Carcinogenic aspects of protein phosphatase 1 and 2A inhibitors. In Marine Toxins as Research Tools; Springer: Berlin/Heidelberg, Germany, 2009; pp. 221-254.

68. Nishiwaki-Matsushima, R.; Ohta, T.; Nishiwaki, S.; Suganuma, M.; Kohyama, K.; Ishikawa, T.; Carmichael, W.W.; Fujiki, H. Liver tumor promotion by the cyanobacterial cyclic peptide toxin microcystin-LR. J. Cancer Res. Clin. Oncol. 1992, 118, 420-424. [CrossRef]

69. Herfindal, L.; Selheim, F. Microcystin produces disparate effects on liver cells in a dose dependent manner. Mini Rev. Med. Chem. 2006, 6, 279-285. [CrossRef]

70. Carmichael, W.W.; Azevedo, S.M.; An, J.S.; Molica, R.J.; Jochimsen, E.M.; Lau, S.; Rinehart, K.L.; Shaw, G.R.; Eaglesham, G.K. Human fatalities from cyanobacteria: chemical and biological evidence for cyanotoxins. Environ. Health Perspect. 2001, 109, 663-668. [CrossRef]

71. Yuan, M.; Carmichael, W.W.; Hilborn, E.D. Microcystin analysis in human sera and liver from human fatalities in Caruaru, Brazil 1996. Toxicon 2006, 48, 627-640. [CrossRef]

72. Texeira, M.D.G.L.C.; Costa, M.D.C.N.; Carvalho, V.L.P.D.; Pereira, M.D.S.; Hage, E. Gastroenteritis epidemic in the area of the Itaparica Dam, Bahia, Brazil. Bull. Paho 1993, 27, 1993.

73. Jochimsen, E.M.; Carmichael, W.W.; An, J.; Cardo, D.M.; Cookson, S.T.; Holmes, C.E.; Antunes, M.B.; de Melo Filho, D.A.; Lyra, T.M.; Barreto, V.S.T. Liver failure and death after exposure to microcystins at a hemodialysis center in Brazil. N. Engl. J. Med. 1998, 338, 873-878. [CrossRef]

74. Pouria, S.; de Andrade, A.; Barbosa, J.; Cavalcanti, R.; Barreto, V.; Ward, C.; Preiser, W.; Poon, G.K.; Neild, G.; Codd, G. Fatal microcystin intoxication in haemodialysis unit in Caruaru, Brazil. Lancet 1998, 352, $21-26$. [CrossRef]

75. Azevedo, S.M.; Carmichael, W.W.; Jochimsen, E.M.; Rinehart, K.L.; Lau, S.; Shaw, G.R.; Eaglesham, G.K. Human intoxication by microcystins during renal dialysis treatment in Caruaru-Brazil. Toxicology 2002, 181, 441-446. [CrossRef]

76. Giannuzzi, L.; Sedan, D.; Echenique, R.; Andrinolo, D. An acute case of intoxication with cyanobacteria and cyanotoxins in recreational water in Salto Grande Dam, Argentina. Mar. Drugs 2011, 9, 2164-2175. [CrossRef]

77. Vidal, F.; Sedan, D.; D'Agostino, D.; Cavalieri, M.L.; Mullen, E.; Parot Varela, M.M.; Flores, C.; Caixach, J.; Andrinolo, D. Recreational exposure during algal bloom in Carrasco Beach, Uruguay: A liver failure case report. Toxins 2017, 9, 267. [CrossRef] [PubMed]

78. Zilberg, B. Gastroenteritis in Salisbury European children-a five-year study. Cent. Afr. J. Med. 1966, 12, 164-168. [PubMed]

79. Annadotter, H.; Cronberg, G.; Lawton, L.; Hansson, H.-B.; Göthe, U.; Skulberg, O. An extensive outbreak of gastroenteritis associated with the toxic cyanobacterium Planktothrix agardhii (Oscillatoriales, Cyanophyceae) in Scania, South Sweden. In Cyanotoxins; Springer: Berlin, Germany, 2001; pp. 200-208.

80. Milutinović, A.; Živin, M.; Zorc-Pleskovič, R.; Sedmak, B.; Šuput, D. Nephrotoxic effects of chronic administration of microcystins-LR and-YR. Toxicon 2003, 42, 281-288. [CrossRef]

81. Milutinović, A.; Sedmark, B.; Horvat-Žnidaršić, I.; Šuput, D. Renal injuries induced by chronic intoxication with microcystins. Cell Mol. Biol. Lett. 2002, 7, 139-141.

82. Nobre, A.; Jorge, M.; Menezes, D.; Fonteles, M.; Monteiro, H. Effects of microcystin-LR in isolated perfused rat kidney. Braz. J. Med. Biol. Res. 1999, 32, 985-988. [CrossRef]

83. Botha, N.; van de Venter, M.; Downing, T.G.; Shephard, E.G.; Gehringer, M.M. The effect of intraperitoneally administered microcystin-LR on the gastrointestinal tract of Balb/c mice. Toxicon 2004, 43, 251-254. [CrossRef]

84. Žegura, B.; Volčič, M.; Lah, T.T.; Filipič, M. Different sensitivities of human colon adenocarcinoma (CaCo-2), astrocytoma (IPDDC-A2) and lymphoblastoid (NCNC) cell lines to microcystin-LR induced reactive oxygen species and DNA damage. Toxicon 2008, 52, 518-525. [CrossRef] 
85. Dias, E.; Andrade, M.; Alverca, E.; Pereira, P.; Batoréu, M.; Jordan, P.; Silva, M.J. Comparative study of the cytotoxic effect of microcistin-LR and purified extracts from Microcystis aeruginosa on a kidney cell line. Toxicon 2009, 53, 487-495. [CrossRef] [PubMed]

86. De Figueiredo, D.R.; Azeiteiro, U.M.; Esteves, S.M.; Gonçalves, F.J.; Pereira, M.J. Microcystin-producing blooms-a serious global public health issue. Ecotoxicol. Environ. Saf. 2004, 59, 151-163. [CrossRef] [PubMed]

87. Gorham, P.; Carmichael, W. Hazards of freshwater blue-green algae (cyanobacteria). In Algae and Human Affairs; Lembi, C.A., Waaland, J.R., Eds.; Cambridge University Press: Cambridge, UK, 1988; Sponsored by the Phycological Society of America, Inc.

88. Nagata, S.; Soutome, H.; Tsutsumi, T.; Hasegawa, A.; Sekijima, M.; Sugamata, M.; Harada, K.I.; Suganuma, M.; Ueno, Y. Novel monoclonal antibodies against microcystin and their protective activity for hepatotoxicity. Nat. Toxins 1995, 3, 78-86. [CrossRef]

89. Dawson, R. The toxicology of microcystins. Toxicon 1998, 36, 953-962. [CrossRef]

90. Gehringer, M.M.; Govender, S.; Shah, M.; Downing, T.G. An investigation of the role of vitamin E in the protection of mice against microcystin toxicity. Environ. Toxicol. Int. J. 2003, 18, 142-148. [CrossRef]

91. World Health Organization. Guidelines for Drinking-Water Quality. Volume 2, Health Criteria and Other Supporting Information: Addendum; World Health Organization: Geneva, Switzerland, 1998; Available online: https: //apps.who.int/iris/bitstream/handle/10665/63844/WHO_EOS_98.1.pdf?sequence=1\&isAllowed=y (accessed on 22 May 2020).

92. Metcalf, J.; Bell, S.; Codd, G. Production of novel polyclonal antibodies against the cyanobacterial toxin microcystin-LR and their application for the detection and quantification of microcystins and nodularin. Water Res. 2000, 34, 2761-2769. [CrossRef]

93. Zweigenbaum, J.; Henion, J.; Beattie, K.; Codd, G.; Poon, G. Direct analysis of microcystins by microbore liquid chromatography electrospray ionization ion-trap tandem mass spectrometry. J. Pharm. Biomed. Anal. 2000, 23, 723-733. [CrossRef]

94. Ward, C.J.; Beattie, K.A.; Lee, E.Y.; Codd, G.A. Colorimetric protein phosphatase inhibition assay of laboratory strains and natural blooms of cyanobacteria: Comparisons with high-performance liquid chromatographic analysis for microcystins. FEMS Microbiol. Lett. 1997, 153, 465-473. [CrossRef]

95. Carmichael, W.W.; An, J.J. Using an enzyme linked immunosorbent assay (ELISA) and a protein phosphatase inhibition assay (PPIA) for the detection of microcystins and nodularins. Nat. Toxins 1999, 7, 377-385. [CrossRef]

96. Ueno, Y.; Nagata, S.; Tsutsumi, T.; Hasegawa, A.; Yoshida, F.; Suttajit, M.; Mebs, D.; Pütsch, M.; Vasconcelos, V. Survey of microcystins in environmental water by a highly sensitive immunoassay based on monoclonal antibody. Nat. Toxins 1996, 4, 271-276. [CrossRef]

97. Zeck, A.; Weller, M.G.; Bursill, D.; Niessner, R. Generic microcystin immunoassay based on monoclonal antibodies against Adda. Analyst 2001, 126, 2002-2007. [CrossRef] [PubMed]

98. Lindner, P.; Molz, R.; Yacoub-George, E.; Dürkop, A.; Wolf, H. Development of a highly sensitive inhibition immunoassay for microcystin-LR. Anal. Chim. Acta 2004, 521, 37-44. [CrossRef]

99. Lindner, P.; Molz, R.; Yacoub-George, E.; Wolf, H. Rapid chemiluminescence biosensing of microcystin-LR. Anal. Chim. Acta 2009, 636, 218-223. [CrossRef]

100. Fontal, O.; Vieytes, M.; de Sousa, J.B.; Louzao, M.; Botana, L.J.A.b. A fluorescent microplate assay for microcystin-LR. Anal. Biochem. 1999, 269, 289-296. [CrossRef]

101. Tippkötter, N.; Stückmann, H.; Kroll, S.; Winkelmann, G.; Noack, U.; Scheper, T.; Ulber, R. A semi-quantitative dipstick assay for microcystin. Anal. Bioanal. Chem. 2009, 394, 863-869. [CrossRef]

102. Spoof, L.; Vesterkvist, P.; Lindholm, T.; Meriluoto, J. Screening for cyanobacterial hepatotoxins, microcystins and nodularin in environmental water samples by reversed-phase liquid chromatography-electrospray ionisation mass spectrometry. J. Chromatogr. A 2003, 1020, 105-119. [CrossRef]

103. Lawton, L.A.; Edwards, C.; Codd, G.A. Extraction and high-performance liquid chromatographic method for the determination of microcystins in raw and treated waters. Analyst 1994, 119, 1525-1530. [CrossRef]

104. Douma, M.; Ouahid, Y.; Del Campo, F.; Loudiki, M.; Mouhri, K.; Oudra, B. Identification and quantification of cyanobacterial toxins (microcystins) in two Moroccan drinking-water reservoirs (Mansour Eddahbi, Almassira). Environ. Monit. Assess. 2010, 160, 439. [CrossRef]

105. Neffling, M.-R.; Spoof, L.; Meriluoto, J. Rapid LC-MS detection of cyanobacterial hepatotoxins microcystins and nodularins-Comparison of columns. Anal. Chim. Acta 2009, 653, 234-241. [CrossRef] 
106. Barco, M.; Rivera, J.; Caixach, J. Analysis of cyanobacterial hepatotoxins in water samples by microbore reversed-phase liquid chromatography-electrospray ionisation mass spectrometry. J. Chromatogr. A 2002, 959, 103-111. [CrossRef]

107. Cong, L.; Huang, B.; Chen, Q.; Lu, B.; Zhang, J.; Ren, Y. Determination of trace amount of microcystins in water samples using liquid chromatography coupled with triple quadrupole mass spectrometry. Anal. Chim. Acta 2006, 569, 157-168. [CrossRef]

108. Mekebri, A.; Blondina, G.; Crane, D. Method validation of microcystins in water and tissue by enhanced liquid chromatography tandem mass spectrometry. J. Chromatogr. A 2009, 1216, 3147-3155. [CrossRef] [PubMed]

109. Via-Ordorika, L.; Fastner, J.; Kurmayer, R.; Hisbergues, M.; Dittmann, E.; Komarek, J.; Erhard, M.; Chorus, I. Distribution of microcystin-producing and non-microcystin-producing Microcystis sp. In European freshwater bodies: Detection of microcystins and microcystin genes in individual colonies. Syst. Appl. Microbiol. 2004, 27, 592-602. [CrossRef]

110. Miguel, M. Mozambique - AFRICA- P125120- Greater Maputo Water Supply Expansion Project - Procurement Plan (English); World Bank: Washington, DC, USA, 2019.

111. Republic, M. Integrated Water Supply and Sanitation Project for the Provinces of Niassa and Nampula-MOZ/PWWS/2000/01; African Development Fund: Maputo, Mozambique, 2000.

112. Housing, M.o.P.W.a. National Rural Water Supply and Sanitation Program (PRONASAR) in Nampula and Zambezia Provinces; African Development Bank Group: Maputo, Mozambique, 2010.

113. Canada, G.o.C.-G.A. Inhambane Rural Water Supply and Sanitation Program; Global Affairs Canada: Maputo, Mozambique, 2017.

114. Uandela, A. Mecanismos e Instrumentos de Planificação e Orçamentação no Sector de águas em Moçambique. Folheto Informativo Moç. M03. 2012, pp. 1-11. Available online: https://www.ircwash.org/sites/default/files/m03_mecanismos_e_instrumentos_de_planificacao_e_o ramentacao_no_sector_de_aguas_em_mocambique.pdf (accessed on 22 May 2020).

115. Water Sanitation; World Health Organization. Guidelines for Drinking-Water Quality [Electronic Resource]: Incorporating First Addendum. Vol. 1, Recommendations; ONU News, Maputo, Mozambique 2006. Available online: https://news.un.org/pt/story/2019/06/1675251 (accessed on 22 May 2020).

116. Pota, O. Em Moçambique, mais de 500 mil pessoas tiveram doenças causadas por consumo de alimentos inseguros. ONU News, 7 June 2019.

117. Pedro, O.; Rundberget, T.; Lie, E.; Correia, D.; Skaare, J.U.; Berdal, K.G.; Neves, L.; Sandvik, M. Occurrence of microcystins in freshwater bodies in Southern Mozambique. J. Res. Environ. Sci. Toxicol. 2012, 1, $58-65$.

118. Pedro, O.; Correia, D.; Lie, E.; Skåre, J.U.; Leão, J.; Neves, L.; Sandvik, M.; Berdal, K.G. Polymerase chain reaction (PCR) detection of the predominant microcystin-producing genotype of cyanobacteria in Mozambican lakes. Afr. J. Biotechnol. 2011, 10, 19299-19308.

119. Pedro, O.; Lie, E.; Correia, D.; Neves, L.; Skaare, J.U.; Sandvik, M.; Berdal, K.G. Quantification of microcystin-producing microcystis in freshwater bodies in the Southern Mozambique using quantitative real time polymerase chain reaction. Afr. J. Biotechnol. 2013, 12. [CrossRef]

120. Bojcevska, H.; Jergil, E. Removal of cyanobacterial toxins (LPS endotoxin and microcystin) in drinking-water using the BioSand household water filter. Minor Field Study 2003, 91, 1-44.

121. MD. SAUDE. Regulamento sobre a Qualidade da Água para o Consumo Humano. In Diploma Ministerial 180/2004 de 15 de Setembro; Boletim da Republica, I serie, numero 37; MD. SAUDE: Maputo, Mozambique, 2004; Volume Diploma Ministerial 180/2004.

122. Magonono, M.; Oberholster, P.J.; Shonhai, A.; Makumire, S.; Gumbo, J.R. The presence of toxic and non-toxic Cyanobacteria in the sediments of the Limpopo River Basin: Implications for human health. Toxins 2018, 10, 269. [CrossRef]

123. Fosso-Kankeu, E.; Jagals, P.; Du Preez, H. Exposure of rural households to toxic cyanobacteria in container-stored water. Water SA 2008, 34, 631-636. [CrossRef]

124. Falconer, I.R.; Runnegar, M.T.; Beresford, A.M. Evidence of liver damage by toxin from a bloom of the blue-green alga, Microcystis aeruginosa. Med J. Aust. 1983, 1, 511-514. [CrossRef] [PubMed]

125. Kirumba, W.; Shushu, D.; Masundire, H.; Oyaro, N. Diversity of Algae and Potentially Toxic Cyanobacteria in a River Receiving Treated Sewage Effluent: A case of Notwane River (Gaborone, Botswana). Int. Res. J. Environ. Sci. 2014. 
126. Mbukwa, E.A.; Boussiba, S.; Wepener, V.; Leu, S.; Kaye, Y.; Msagati, T.A.; Mamba, B.B. PCR amplification and DNA sequence of mcyA gene: The distribution profile of a toxigenic Microcystis aeruginosa in the Hartbeespoort Dam, South Africa. J. Water Health 2013, 11, 563-572. [CrossRef]

127. Robarts, R.; Zohary, T. Microcystis aeruginosa and underwater light attenuation in a hypertrophic lake (Hartbeespoort Dam, South Africa). J. Ecol. 1984, 72, 1001-1017. [CrossRef]

128. Jarvis, A.C.; Hart, R.C.; Combrink, S. Zooplankton feeding on size fractionated Microcystis colonies and Chlorella in a hypertrophic lake (Hartbeespoort Dam, South Africa): Implications to resource utilization and zooplankton succession. J. Plankton Res. 1987, 9, 1231-1249. [CrossRef]

129. Zohary, T. Hyperscums of the cyanobacterium Microcystis aeruginosa in a hypertrophic lake (Hartbeespoort Dam, South Africa). J. Plankton Res. 1985, 7, 399-409. [CrossRef]

130. Scott, W.E.; Barlow, D.J.; Hauman, J.H. Studies on the ecology, growth and physiology of toxic Microcystis aeruginosa in South Africa. In The Water Environment; Springer: Berlin/Heidelberg, Germany, 1981; pp. $49-69$.

131. Ballot, A.; Sandvik, M.; Rundberget, T.; Botha, C.J.; Miles, C. Diversity of cyanobacteria and cyanotoxins in Hartbeespoort Dam, South Africa. Mar. Freshw. Res. 2014, 65, 175-189. [CrossRef]

132. Oberholster, P.J.; Myburgh, J.G.; Govender, D.; Bengis, R.; Botha, A.-M. Identification of toxigenic Microcystis strains after incidents of wild animal mortalities in the Kruger National Park, South Africa. Ecotoxicol. Environ. Saf. 2009, 72, 1177-1182. [CrossRef]

133. Scott, W. Occurrence and significance of toxic cyanobacteria in Southern Africa. Water Sci. Technol. 1991, 23, 175-180. [CrossRef]

134. Mokoena, M.; Mukhola, M.; Okonkwo, O. Hazard assessment of microcystins from the household's drinking water. Appl. Ecol. Environ. Res. 2016, 14, 695-710. [CrossRef]

135. Oberholster, P.; Cloete, T.; van Ginkel, C.; Botha, A.; Ashton, P. The use of remote sensing and molecular markers as early warning indicators of the development of cyanobacterial hyperscum crust and microcystin producing genotypes in the hypertrophic Lake Hartebeespoort, South Africa. Pretoria Counc. Sci. Ind. Res. 2008. Available online: https://pdfs.semanticscholar.org/5ff3/c3915fbb680ddcd6a9f5dff1fd247892d541.pdf (accessed on 22 May 2020).

136. Nonga, H.; Sandvik, M.; Miles, C.; Lie, E.; Mdegela, R.; Mwamengele, G.; Semuguruka, W.; Skaare, J. Possible involvement of microcystins in the unexplained mass mortalities of Lesser Flamingo (Phoeniconaias minor Geoffroy) at Lake Manyara in Tanzania. Hydrobiologia 2011, 678, 167-178. [CrossRef]

137. Fyumagwa, R.D.; Bugwesa, Z.; Mwita, M.; Kihwele, E.S.; Nyaki, A.; Mdegela, R.H.; Mpanduji, D.G. Cyanobacterial toxins and bacterial infections are the possible causes of mass mortality of lesser flamingos in Soda lakes in northern Tanzania. Res. Opin. Anim. Vet. Sci. 2013, 3, 1-6.

138. Lugomela, C.; Pratap, H.B.; Mgaya, Y.D. Cyanobacteria blooms-a possible cause of mass mortality of Lesser Flamingos in Lake Manyara and Lake Big Momela, Tanzania. Harmful Algae 2006, 5, 534-541. [CrossRef]

139. Sekadende, B.C.; Lyimo, T.J.; Kurmayer, R. Microcystin production by cyanobacteria in the Mwanza Gulf (Lake Victoria, Tanzania). Hydrobiologia 2005, 543, 299-304. [CrossRef]

140. Mbonde, A.S.; Sitoki, L.; Kurmayer, R. Phytoplankton composition and microcystin concentrations in open and closed bays of Lake Victoria, Tanzania. Aquat. Ecosyst. Health Manag. 2015, 18, 212-220. [CrossRef]

141. Ndebele, M.R.; Magadza, C.H. The occurrence of microcystin-LR in Lake Chivero, Zimbabwe. Lakes Reserv. Res. Manag. 2006, 11, 57-62. [CrossRef]

142. Mhlanga, L.; Day, J.; Cronberg, G.; Chimbari, M.; Siziba, N.; Annadotter, H. Cyanobacteria and cyanotoxins in the source water from Lake Chivero, Harare, Zimbabwe, and the presence of cyanotoxins in drinking water. Afr. J. Aquat. Sci. 2006, 31, 165-173. [CrossRef]

143. Gondwe, M.J.; Guildford, S.J.; Hecky, R.E. Planktonic nitrogen fixation in Lake Malawi/Nyasa. Hydrobiologia 2008, 596, 251-267. [CrossRef]

144. Liu, I.; Lawton, L.A.; Cornish, B.; Robertson, P.K. Mechanistic and toxicity studies of the photocatalytic oxidation of microcystin-LR. J. Photochem. Photobiol. A Chem. 2002, 148, 349-354. [CrossRef]

145. Yuan, B.; Li, Y.; Huang, X.; Liu, H.; Qu, J. Fe (VI)-assisted photocatalytic degradating of microcystin-LR using titanium dioxide. J. Photochem. Photobiol. A Chem. 2006, 178, 106-111. [CrossRef]

146. Pavagadhi, S.; Tang, A.L.L.; Sathishkumar, M.; Loh, K.P.; Balasubramanian, R. Removal of microcystin-LR and microcystin-RR by graphene oxide: Adsorption and kinetic experiments. Water Res. 2013, 47, 4621-4629. [CrossRef] 
147. Chintalapati, P.; Mohseni, M. Degradation of cyanotoxin microcystin-LR in synthetic and natural waters by chemical-free UV/VUV radiation. J. Hazard. Mater. 2020, 381, 120921. [CrossRef] [PubMed]

148. Pendleton, P.; Schumann, R.; Wong, S.H. Microcystin-LR adsorption by activated carbon. J. Colloid Interface Sci. 2001, 240, 1-8. [CrossRef] [PubMed]

149. Zhang, H.; Zhu, G.; Jia, X.; Ding, Y.; Zhang, M.; Gao, Q.; Hu, C.; Xu, S. Removal of microcystin-LR from drinking water using a bamboo-based charcoal adsorbent modified with chitosan. J. Environ. Sci. 2011, 23, 1983-1988. [CrossRef]

150. Song, H.-L.; Lv, X.-L.; Li, X.-L. Safety Improvement for Drinking Water in Rural Region by Hydrophyte Filter Bed. China Water Wastewater 2006, 22, 17-20.

151. Guang-can, Z.; Xi-wu, L. Removal of Microcystins by Biological Activated Carbon Process. China Water Wastewater 2005, 2, 14-17.

152. Song, H.-L.; Li, X.-N.; Lu, X.-W.; Inamori, Y. Investigation of microcystin removal from eutrophic surface water by aquatic vegetable bed. Ecol. Eng. 2009, 35, 1589-1598. [CrossRef]

153. Warhurst, A.; Raggett, S.; McConnachie, G.; Pollard, S.; Chipofya, V.; Codd, G. Adsorption of the cyanobacterial hepatotoxin microcystin-LR by a low-cost activated carbon from the seed husks of the pan-tropical tree, Moringa oleifera. Sci. Total Environ. 1997, 207, 207-211. [CrossRef]

(C) 2020 by the authors. Licensee MDPI, Basel, Switzerland. This article is an open access article distributed under the terms and conditions of the Creative Commons Attribution (CC BY) license (http://creativecommons.org/licenses/by/4.0/). 